\title{
Efektifitas Mata Kuliah Al Islam Kemuhammadiyahan dalam Pembentukan Akhlakul Karimah Mahasiswa (Studi Deskriptif Analitis di Universitas Muhammadiyah Pekajangan Pekalongan)
}

\author{
Gigih Setianto \\ Program Studi Fisioterapi, Fakultas Ilmu Kesehatan Universitas Muhammadiyah Pekajangan Pekalongan \\ Email: gigihsetianto@gmail.com
}

\section{Risdiani}

Program Studi Pendidikan Jasmani, Fakultas Ilmu Kesehatan Universitas Muhammadiyah Pekajangan Pekalongan Email: risdiani08@gmail.com

\begin{tabular}{|c|c|}
\hline \multirow{2}{*}{$\begin{array}{l}\text { Submission } \\
\text { Track: }\end{array}$} & ABSTRACT \\
\hline & \\
\hline Received: & $\begin{array}{l}\text { This article discusses the effectiveness of Al-Islam and Muhammadiyah courses } \\
\text { in constructing the morality of students at the University of Muhammadiyah } \\
\text { Pekajangan Pekalongan. This article was written using a qualitative descriptive }\end{array}$ \\
\hline 6 Agustud 2020 & approach with data collection techniques took the form of observation, \\
\hline Final Revision: & $\begin{array}{l}\text { documentation and interviews. Through the use of these methods, this article } \\
\text { found that Al-Islam and Muhammadiyah courses were effective in constructing }\end{array}$ \\
\hline 1 Sepetember 2020 & good morality of the students, both in terms of their 'noble characters' \\
\hline Available online: & $\begin{array}{l}\text { (akhlakul karimah) towards Allah, themselves, their family, other people and } \\
\text { environment. More specifically, the construction of noble characters towards }\end{array}$ \\
\hline 25 September 2020 & Allah includes absolute monotheism, praying only to Allah, abstain from \\
\hline Corresponding & $\begin{array}{l}\text { believing in superstition, abstain from maintaining amulets, abstain from } \\
\text { visiting shamans, being grateful for Allah's blessings, being patient with worldly }\end{array}$ \\
\hline Author: & tests from Allah, worshiping Allah well and properly. The construction of noble \\
\hline Name \& E-mail Address & $\begin{array}{l}\text { characters towards students themselves includes being honest, being a hard } \\
\text { worker, trustworthy, disciplined, simple, polite, confident and willing to }\end{array}$ \\
\hline Gigih Setianto & $\begin{array}{l}\text { introspect. The construction of noble characters towards the family includes } \\
\text { being devoted to their parents, establishing friendship with the family members }\end{array}$ \\
\hline gigihsetianto@gmail.com & maintaining good communication with the family, caring for family members, \\
\hline Risdiani & $\begin{array}{l}\text { easing their parents' burden. The construction of noble characters towards } \\
\text { others includes caring for 'the weak and the helpless' (mustadzafin), caring to }\end{array}$ \\
\hline risdiani08@gmail.com & $\begin{array}{l}\text { help others, establishing mutual cooperation, and tolerance. At the same time, } \\
\text { the construction of noble characters towards the environment includes keeping } \\
\text { it clean, using water wisely, reducing plastic waste, rejecting mining which } \\
\text { potentially damages the environment, preserving the environment by planting } \\
\text { trees and taking care of animals. }\end{array}$ \\
\hline
\end{tabular}

Keywords : Efektifitas, Al Islam dan Kemuhammadiyahan, Akblakul Karimah

\section{PENDAHULUAN}

Globalisasi membawa pengaruh nilai budaya yang memiliki dua sisi secara diametral yaitu pengaruh positif dan pengaruh negatif.(Shindunata, 2000) Pengaruh positif globalisasi menjadikan manusia mudah dalam melakukan aktifitas apapun yang terkait dengan penggunaan ilmu pengetahuan dan
teknologi.(Suhaimi, 2014) Manusia dapat terbantu dalam menyelesaikan aktifitasnya tanpa terkendala apapun secara simultan dalam waktu yang relatif singkat. Di samping pengaruh positif dari globalisasi, maka sudah pasti menimbulkan pengaruh negatif yang bisa jadi lebih besar dibandingkan dengan pengaruh positifnya, diantaranya adalah pergeseran budaya 
yang tidak sesuai dengan perspektif Islam dan kurang sesuai dengan budaya Bangsa yang sudah tertanam dengan baik sebagai warisan adiluhung budaya Bangsa Indonesia. Ditambah lagi, munculnya masyarakat masa depan yang penuh dengan ketidakpastian.(Lestari \& Ngatini, 2010) Tidak setiap warga negara menyikapi dampak negatif globalisasi dengan baik. Terjadinya penurunan kuwalitas moral bangsa merupakan salah satu dampak negatif dari globalisasi. Adapun penurunan uwalitas moral bangsa dapat kita lihat banyaknya bermunculan kasus-kasus yang tidak sesuai dengan nilai-nilai norma yang hidup dalam masyarakat indonesia, seperti: maraknya pencurian, pembunuhan, pemerkosaan dikalangan masyarakat serta kasus-kasus kenakalan remaja seperti tawuran, sex bebas dan penyalahgunaan narkoba terutama yang terjadi dikalangan pelajar. Beberapa kasus diatas menunjukkan bahwa pendidikan kita belum mampu membangun karakter bangsa. Karena, hingga saat ini praktik pendidikan yang terjadi dikelas-kelas tidak lebih dari latihan-latihan skolastik, seperti mengenal, membandingkan, melatih, dan menghafal.( Surahmad., et. al, 2003)

Tidak terkecuali di perguruan tinggi, tidak sedikit akhlak mahasiswa mengalami kerusakan sebagai akibat dari pengaruh negatif tersebut. Oleh karena itu diperlukan langkahlangkah untuk membendung pengaruh negatif dari globalisasi. Perguruan Tinggi yang menjadi pembahasan dalam penelitian ini adalah Universitas Muhammadiyah Pekajangan Pekalongan.

$$
\text { Perguruan Tinggi ini telah }
$$

merealisasikan Catur Dharma Perguruan Tinggi yaitu Pendidikan, Penelitian Pengabdian kepada Masyarakat dan Al Islam Kemuhammadiyahan. Sesuai dengan catur dharma diatas bahwa sebagai ciri khusus dari perguruan Tinggi Muhammadiyah adalah dengan adanya darma ke empat yaitu Al Islam dan Kemuhammadiyahan yang salah satu implementasinya adalah adanya perkuliahan Al Islam dan Kemuhammadiyahan (AIK) yang intensif dilaksanakan selama lima semester dan bersifat wajib untuk ditempuh oleh semua mahasiswa. Adapun rumusan masalah yang diangkat dalam penelitian ini yaitu: (1) Bagaimana eksistensi matakuliah Al Islam dan Kemuhammadiyahan (AIK) di Universitas Muhammadiyah Pekajangan Pekalongan (UMPP)?; (2) Bagaimana efektifitas matakuliah Al Islam dan Kemuhammadiyahan (AIK) di Universitas Muhammadiyah Pekajangan Pekalongan dalam pembentukan akhlakul karimah mahasiswa?

$$
\text { Pendidikan Al Islam dan }
$$
Kemuhammadiyahan (AIK) Visi Pendidikan Muhammadiyah sebagaimana tertuang dalam Putusan Muktamar Muhammadiyah ke 46 tentang Revitalisasi Pendidikan Muhammadiyah: "Terbentuknya manusia pembelajar yang bertaqwa, berakhlak mulia, berkemajuan dan unggul dalam ipteks sebagai perwujudan tajdid dakwah amar ma'ruf nahi munkar".(Tim Pimpinan Pusat Muhammadiyah, 2010). Visi Perguruan Tinggi Muhammadiyah (PTM) sebagaimana dirumuskan oleh Majlis Dikti PP Muhammadiyah adalah "Terbangunnya tata kelola PTM yang baik (good governance) 
menuju peningkatan mutu berkelanjutan". Visi tersebut mengharuskan PTM meningkatkan mutu dalam berbagai aspek termasuk pendidikan Al Islam dan Kemuhammadiyahan (AIK). PTM mengemban amanah untuk mewujudkan salah satu misi Muhammadiyah yaitu menyelenggarakan pendidikan AIK sebagai bagian dari dakwah amar makruf nahi munkar. Pendidikan AIK di PTM memiliki posisi strategis, menjadi ruh penggerak, dan misi utama penyelenggaraan PTM. Pendidikan AIK juga menjadi kekuatan PTM karena dapat menjadi basis kekuatan spiritual, moral dan intelektual serta daya gerak bagi seluruh civitas akademika. Keberhasilan pendidikan AIK menjadi salah satu indikator ketercapaian misi penyelenggaraan dan pengelolaan PTM. Peningkatan mutu proses dan hasil (outcome) pendidikan AIK harus dilaksanakan terus menerus dan tersistem. Pengembangan kurikulum pendidikan AIK ini dilakukan sesuai amanah keputusan Muktamar Muhammadiyah ke 46 tentang Program Muhammadiyah 2010-2015 yaitu: "Mengembangkan model-model pendidikan AlIslam dan Kemuhammadiyahan di seluruhjenjang pendidikan yang memberikan pencerahan paham Islam dan komitmen gerakan Muhammadiyah yang berkemajuan".(Tim Pimpinan Pusat Muhammadiyah, 2010, hlm. 118)

Sebagaimana ketentuan Pedoman pimpinan Pusat Muhammadiyah Nomor 02/PEDI/ I.0/B/2012 tentang Perguruan Tinggi Muhammadiyah. Pada Pasal 9 ayat (2) terdapat ketentuan sebagai berikut: Perguruan
Tinggi Muhammadiyah wajib memiliki ciri khas kurikulum Al-Islam Kemuhammadiyahan yang diatur lebih lanjut dengan ketentuan Majelis Pendidikan Tinggi." Dari ketentuan ini dapat dipahami bahwa Al Islam dan Kemuhammadiyahan (AIK) merupakan salah satu ciri khas Perguruan Tinggi Muhammadiyah (PTM). Dan konsekuensi dari ketentuan ini, semua PTM di seluruh Indonesia wajib menyelenggarakan pendidikan AIK sejak semester awal. AIK merupakan mata kuliah yang sejenis dengan pendidikan agama Islam (PAI) di perguruan tinggi umum yang wajib diikuti oleh mahasiswa yang beragama Islam. Hanya saja kalau PAI cukup diberikan satu semester, sedangkan AIK bisa sampai empat semester bahkan bisa lebih. Dalam buku pedoman pendidikan Al Islam dan Kemuhammadiyahan perguruan Tinggi Muhammadiyah dijelaskan bahwa AIK diberikan dalam empat tahapan dengan rincian: AIK I (Kemanusiaan dan Keimanan), AIK II (Ibadah, akhlak dan muamalah), AIK III (Kemuhammadiyahan) dan AIK IV (Islam dan Ilmu Pengetahuan).

AIK di Perguruan Tinggi Muhammadiyah (PTM) memandang Islam sebagai petunjuk kepada jalan yang lurus, modal sosial, jalan menuju Tuhan, dan jalan kebahagiaan hidup didunia dan akhirat. Tujuan pendidikan AIK untuk membentuk insan berkarakter dan insan terpelajar yang diharapkan memiliki integritas dan kesadaran etis. Dalam AlQur'an surat al-Qashash ayat 77 Allah berfirman yang artinya: “...dan berbuat baiklah sebagaimana Allah telah berbuat baik kepadamu..." 
Bagi insan terpelajar, beramal shaleh baik yang bersifat ritual maupun sosial seharusnya tidak didasarkan pada faktor dari luar dirinya (ganjaran dan ancaman), melainkan sebagai bentuk panggilan etis, beramal shaleh sebagai manifestasi rasa terimakasih kepada Allah dan sesama. Pendidikan AIK untuk membentuk manusia berkemajuan, berjiwa pengasih, dan penuh kasih kepada sesama (philantropis).(Tim Pedoman Pendidikan AIK Majlis Dikti PP Muhammadiyah, 2013)

Materi Pokok Kurikulum AIK, Isi pendidikan AIK adalah ilmu pengetahuan tentang Islam baik aspek normatif maupun historis. Materi pokok Pendidikan AIK selama ini meliputi lima aspek: al-Qur'an Hadits, Aqidah, Akhlak, Fiqih, dan Kemuhammadiyahan. Materi pokok AIK ini isamping memiliki kelebihan juga ada kelemahannya. Kelebihannya lebih bersifat akademis dan kelemahannya adalah kurang dalam memfungsikan agama sebagai andasan moral, motivasional dan spiritual dalam memecahkan problem kehidupan.

Materi AIK lebih diarahkan pada pengembangkan karakter manusia baik (saleh dan ihsan) yang berbuat baik bagi kepentingan seluruh manusia (muslim dan non-muslim) sebagai bukti keislaman seorang muslim (AlQuran, SuratAl-Baqarah ayat 176) (Laitsal birra antuwallu wujuhakum....). Al-Qur'an maupun Hadits mengemukakan bahwa Islam itu adalah petunjuk hidup untuk manusia di dunia. Isi kandungan al-Qur'an mencakup seluruh komponen perjalanan hidup manusia mulai dari alam ruh sampai alam akhirat yang meliputi: Tuhan, manusia, alam, penciptaan dan keselamatan. Isi pokok materi AIK perlu direkonstruksi dari keilmuan normatif dan historis Islam kepada dimensi-dimensi kehidupan. Dengan cara inilah mahasiswa dapat kembali kepada al-Qur'an dan Hadits secara cerdas dan fungsional. (Tim Pedoman Pendidikan AIK Majlis Dikti PP Muhammadiyah, 2013)

\section{Pengertian Akhlak dan Akhlakul}

Karimah, Dilihat dari segi bahasa, kata akhlak berasal dari bahasa arab yang telah terserap kedalam bahasa Indonesia. Dalam bahasa arab kata akhlak merupakan bentuk jama' dari kata khuluqun yang berarti tabi'at, perangai, adat kebiasaan, perwira dan agama.(Rajab, 1961, hlm. 13)

Hamzah Yaqub mengatakan bahwa kata khuluqun mempunyai akar yang sama dengan kata khulqun (kejadian) dan erat hubungannya dengan Khaliq (pencipta) dan makhluq (yang diciptakan). Oleh karena itu persoalan yang dibicarakan dalam akhlak tidak hanya terbatas pada baik dan buruknya tabiat, perangai dan adat kebiasaan atau perilaku manusia dalam kehidupan sehari-hari namun juga membahas persoalan mengenai hubungan antara manusia sebagai makhluk dengan Allah Tuhan yang Maha Pencipta (Kholiq), hubungan manusia dengan dirinya sendiri, hubungan manusia dengan sesama manusia dan hubungan manusia dengan makhluk yang lainnya.(Yakub, 1983)

Istilah akhlak bersumber dari kalimat yang tercantum dalam Alquran dan hadis 
Rosulullah saw. Omar Muhammad Al Taommy Assyaibani dalam bukunya yang berjudul "Falsafah Pendidikan Islam" menyatakan bahwa di dalam al Quran terdapat 1504 ayat yang berhubungan dengan masalah akhlak, baik secara teoritis maupun praktis atau secara langsung maupun tidak langsung. Jadi hampir seperempat ayat-ayat Alquran berisi masalah-masalah yang berkaitan dengan akhlak (Assyaibani, 1972). Kenyataan ini mengindikasikan bahwa masalah akhlak merupakan masalah yang sangat esensial dalam kehidupan manusia sehari-hari.

Sedang istilah akhlak/khuluq yang digunakan dalam hadis Rosulullah saw jumlahnya cukup banyak dan pada umumnya digunakan dalam konteks yang berbeda-beda walaupun isinya mengarah kepada maksud yang sama.(Suraji, 2006)

Kata akhlak/khuluq dalam beberapa hadits mengandung arti yang sama yaitu: budi pekerti, tabiat, perangai, adat kebiasaan atau perilaku sehari-hari. Dengan demikian istilah akhlak/khuluq yang dipakai dalam al-Quran maupun hadis Rasulullah dilihat dari segi bahasa mengandung arti yang sama yaitu: budi pekerti, tabiat, perangai, adat kebiasaan atau perilaku sehari-hari.

Sedangkan pengertian akhlak dilihat dari segi istilah diantaranya adalah: Menurut $\mathrm{Al}$ Ghazali dalam Ihya Ulumuddin dinyatakan bahwa: Khuluq (akhlak) adalah ungkapan dari suatu sifat yang tetap dalam jiwa yang dari padanya timbul perbuatan yang mudah dengan tidak memerlukan pemikiran dan pertimbangan terlebih dahulu (al Ghozali, 1967). Sedangkan
Menurut Muhammad Abdul Aziz Al Khuly sebagaimana dikutip oleh Amin Syukur menyatakan bahwa Khuluq (akhlak) adalah sifat jiwa yang sudah terlatih demikian kuatnya sehingga mudahlah bagi yang empunya melakukan suatu tindakan tanpa dipikir dan direnungkan lagi (Syukur, 2010). Ibnu Maskawaih dalam buku Tabdzib al-Akhlaq Wa Tathbir al-A'raq menyebutkan bahwa Khuluq (akhlak) adalah keadaan jiwa seseorang yang mendorong untuk melakukan sesuatu perbuatan tanpa melalui pemikiran dan dipertimbangkan terlebih dahulu.(Maskawaih, 1934). Sedangkan Menurut Muhammad Ibnu Qoyyim sebagai mana dikutip oleh Amin Syukur dijelaskan bahwa Akhlak adalah perangai atau tabiat, yaitu ibarat dari suatu sifat batin dan jiwa yang dimiliki oleh semua manusia (Syukur, 2010). Ahmad Amin dalam bukunya "Kitab Al -Akhlak" merumuskan pengertian akhlak sebagai kehendak yang dibiasakan, maksudnya kehendak itu bila membiasakan sesuatu, maka kebiasaan itu dinamakan akhlak".(Amin, tt)

Sedangkan akhlakul karimah sebagaimana menjadi fokus pada artikel ini memiliki pengertian sebagai akhlak yang terpuji, baik, mulia dan terhormat. Dalam istilah lain yang populer, akhlakul karimah juga sering disebut dengan akhlakul mahmudah. Sudarno Shobron mengutip al Ghozali menjelaskan bahwa berakhlakul karimah adalah menghilangkan semua adat kebiasaan yang tercela yang sudah dijelaskan oleh agama Islam serta menjauhkan diri dari padanya sebagaimana menjauhkan diri dari najis dan kotoran. Setelah 
itu membiasakan diri dengan adat kebiasaan yang baik, menggemarinya, melakukannya dan mencintainya. Untuk dapat memiliki akhlakul karimah tersebut diperlukan latihan secara terusmenerus.(Shobron, 2015)

Kedudukan Akhlak dan Pendidikan Akhlak, Allah telah menjadikan manusia sebagai makhluk yang sempurna, kesempurnaan itu ditandai dengan berbagai macam kelebihan yang dimiliki manusia dibanding makhluk yang lain. Dengan kelebihannya itu manusia memiliki tugas dan kewajiban yang harus dipertanggungjawabkan di dunia dan akhirat. Dalam melaksanakan tugasnya tersebut manusia sudah pasti membutuhkan manusia yang lainnya, sehingga mau tidak mau harus selalu berhubungan satu sama lainnya dalam kehidupan masyarakat.

Agar hubungan tersebut tetap berjalan dengan baik, maka perlu ada aturan sebagai pedoman untuk menilai baik atau buruknya suatu perbuatan atau boleh tidaknya suatu perbuatan dilakukan. Yang selanjutnya masing masing individu bisa mengetahui mana yang harus dilakukan dan mana yang tidak boleh dilakukan atau harus ditinggalkan. Dari pengetahuan tersebut diharapkan dapat mendorong setiap individu untuk selalu berusaha melakukan perbuatan yang baik dan meninggalkan perbuatan yang buruk, sehingga mereka dapat memiliki akhlakul karimah (akhlak yang baik) dan terhindar dari akhlak yang tercela. Apabila setiap individu memiliki akhlak yang baik, dapat dipastikan kehidupan masyarakat akan berjalan dengan baik dan tertib.
Akhlak merupakan bagian yang tidak terpisahkan dalam kehidupan sehari-hari manusia. Akhlak yang baik akan mengantarkan manusia memperoleh kebahagiaan hidup di dunia dan di akhirat. Sedangkan akhlak yang buruk akan menyengsarakan kehidupan sesorang di dunia maupun di akhirat. Oleh karena itu untuk mencapai kebahagiaan hidup didunia, maka seseorang harus berusaha semaksimal mungkin menghiasi dirinya dengan akhlakul karimah (akhlak yang baik) dan menghindarkan diri dari akhlak yang tercela.

Akhlak yang dimiliki seseorang bukanlah merupakan sesuatu yang dibawa sejak lahir, dan bukan pula merupakan sesuatu yang bersifat tetap, tetapi sesuatu yang dapat berubah, berkembang dan harus dibentuk melalui proses dan waktu yang cukup lama. oleh karena itu pendidikan yang berkelanjutan adalah faktor penting dalam membentuk akhlakul karimah seseorang.

Melihat pentingnya akhlak dalam kehidupan manusia, maka tidak heran jika pakar pendidikan Islam sepakat bahwa terwujudnya akhlakul karimah merupakan salah satu tujuan utama pendidikan dalam Islam. Untuk mencapai tujuan tersebut, maka pendidikan tidak hanya mengajarkan berbagai macam ilmu pengetahuan dan keterampilan tetapi juga pendidikan harus mengajarkan nilai-nilai keutamaan yang diperlukan dalam kehidupan bermasyarakat dan membiasakan anak dengan berbagai macam kesopanan serta mempersiapkan mereka untuk menjalani kehidupan yang penuh dengan kesucian dan kejujuran.(Al Abrashi, 1967) 
Amin Syukur menjelaskan bahwa pembinaan akhlakul karimah dapat ditempuh melalui empat cara: (1) pendidikan, (2) agama dan pendidikan agama, (3) bacaan yang baik, (4) pengalaman sehari-hari. Langkah pertama dalam pembinaan akhlakul karimah adalah melalui pendidikan. Mendidik berarti menolong manusia untuk dapat menjadi anggota masyarakat yang baik dan berguna. Menolong dalam arti membina atau membimbing untuk dapat menjadi manusia dewasa dengan jalan memberikan kepadanya nilai-nilai budaya manusia yakni sifat, tingkah laku, karakter dan watak yang baik, kemudian juga memberikan pengetahuan-pengetahuan, agar terampil dalam mengatasi masalah-masalah hidup yang dihadapi. Jalan pertama yang harus ditempuh untuk menjadikan seseorang memiliki akhlakul karimah adalah melalui pendidikan, baik pendidikan dalam keluarga, pendidikan dalam sekolah maupun pendidikan dalam masyarakat.(Syukur, 2010, hlm. 184-185)

\section{Ruang Lingkup Akhlak, Akhlak} memiliki karakteristik yang universal, artinya ruang lingkup akhlak dalam pandangan Islam sama luasnya dengan ruang lingkup pola hidup dan tindakan manusia dimanapun berada. Secara sederhana ruang lingkup akhlak dibedakan menjadi tiga, yaitu Akhlak terhadap Allah, Akhlak terhadap manusia dan akhlak terhadap alam.

1. Akhlak terhadap Allah, Yang dimaksud akhlak terhadap Allah atau hubungan manusia dengan Allah adalah sikap dan perbuatan yang seharusnya dilakukan oleh manusia terhadap Allah. Akhlak terhadap Allah meliputi beribadah kepada Allah, mentauhidkan Allah, berdoa, berdzikir dan bersyukur serta tunduk dan taat hanya kepada Allah.

2. Akhlak terhadap manusia, Akhlak terhadap manusia digolongkan menjadi tiga yaitu; Akhlak terhadap diri sendiri, akhlak terhadap keluarga, dan akhlak terhadap orang lain atau masyarakat.

a. Akhlak terhadap diri sendiri, Akhlak terhadap diri sendiri adalah pemenuhan kewajiban manusia terhadap dirinya sendiri, baik yang menyangkut jasmani maupun rokhani. Diantara yang termasuk akhlak terhadap diri sendiri adalah jujur dan dapat dipercaya, bersikap sopan santun, sabar, kerjakeras dan disiplin, berjiwa ikhlas, hidup sederhana.

b. Akhlak terhadap keluarga, Hubungan antara orang tua dengan anak, suami dan istri hendaklah terjaga dengan serasi.kewajiban masing masing anggota keluarga dituntut untuk ditunaikan sebaik-baiknya. Demikian juga hak-hak masing masing anggota keluarga harus diberikan seadil-adilnya. Diantara yang termasuk akhlak dalam keluarga adalah Berbuat baik kepada orang tua dan kerabat, menghormati hak hidup anak, membiasakan bermusyawarah, bergaul dengan yang baik,menyantuni saudara yang kurang mampu

c. Akhlak terhadap orang lain (masyarakat), 
Dalam bermasyarakat kita hidup berdampingan dengan orang lain. Dalam hidup kita pasti akan selalu membutuhkan bantuan orang lain. Oleh karena itu berakhlakul karimah terhadap orang lain menjadi suatu keharusan. Terhadap orang lain kita diwajibkan untuk saling tolong menolong dalam berbuat kebaikan. Terhadap orang yang lemah kita harus membantu. Sebaliknya kita dilarang berlaku sombong dan angkuh.

3. Akhlak terhadap alam, Kehidupan manusia memerlukan lingkungan yang bersih, tertib, sehat dan seimbang. Oleh karena itu akhlak terhadap lingkungan, terutama sekali adalah memanfaatkan potensi alam untuk kepentingan hidup manusia. Namun harus tidak boleh boros dan merusak yang berakibat kerusakan alam itu sendiri. Menjaga kebersihan juga merupakan akhlak yang baik terhadap alam. Akhlak yang baik terhadap alam akan dapat mengurangi bencana alam yang setiap saat dapat menimpa kehidupan manusia.

\section{METODE PENELITIAN}

Jenis penelitian ini adalah penelitian lapangan dengan menggunakan pendekatan deskriptif kualitatif (Moleong, 2007), untuk mempelajari temuan yang ada di lapangan, khususnya yang berkaitan dengan efektifitas mata kuliah Al Islam dan Kemuhammadiyahan dalam membentuk akhlakul karimah mahasiswa di Universitas Muhammadiyah Pekajangan Pekalongan.

Penelitian ini dilakukan di Universitas Muhammadiyah Pekajangan Pekalongan. Adapun yang dijadikan subyek penelitian ini adalah pimpinan Universitas, Dosen Al Islam dan Kemuhammadiyahan dan Mahasiswa Universitas Muhammadiyah Pekajangan Pekalongan (Arikunto, 2007). Sesuai dengan jenis penelitian yang digunakan maka teknik pengumpulan data yang digunakan dalam penelitian ini yaitu metode observasi (Margono, 2004). Metode ini digunakan peneliti untuk mengamati beberapa kegiatan terkait pelaksanaan Pembelajaran AIK, serta mengamati perilaku mahasiswa setelah mendapatkan pendidikan AIK. Kemudian teknik pengumpulan data yang kedua yaitu Metode Dokumentasi. Metode ini merupakan metode yang dilakukan dengan cara mengumpulkan data dari berbagai dokumen yang ada di tempat penelitian. Data yang dikumpulkan berupa Profil Universitas Muhammadiyah Pekajangan Pekalongan, Visi Misi, Dokumen Kurikulum, Dokumen Pendidikan dan Pembelajaran AIK serta data lain yang dibutuhkan. Kemudian teknik pengumpulan data berikutnya adalah dengan Metode wawancara. Metode wawancara merupakan salah satu teknik pengumpulan data dengan cara mencari data melalui tanya jawab dengan narasumber yang dilakukan secara lisan (Abdurrahman, 2003). Wawancara dicirikan dengan perbincangan yang dilakukan secara langsung melalui tatap muka antara penanya dan pemberi informasi (Zariah, 2006). Penelitian ini 
memfokuskan wawancara pada pimpinan universitas mengenai visi misi UMPP dan program pendidikan AIK, Wawancara kepada Dosen AIK mengenai rangkaian pembelajaran AIK meliputi proses perencanaan, pengorganisasian dan evaluasi AIK. Wawancara kepada mahasiswa Universitas Muhammadiyah Pekajangan Pekalongan mengenai pendidikan AIK dan perubahan karakter. Peneliti memilih mahasiswa secara acak khususnya mahasiswa Fakultas Ilmu Kesehatan. Langkah-langkah dalam melakukan analisis data selama penelitian adalah reduksi data(Sugiyono, 2010, hlm. 338), penyajian data dan penarikan kesimpulan.

\section{HASIL dan PEMBAHASAN}

Eksistensi mata kuliah Al Islam dan Kemuhammadiyahan (AIK) di Universitas Muhammadiyah Pekajangan Pekalongan (UMPP)

Mata kuliah Al Islam dan Kemuhammadiyahan (AIK) sebagaimana yang tercantum dalam ketentuan Pedoman pimpinan Pusat Muhammadiyah Nomor 02/PEDI/ I.0/B/2012 tentang Perguruan Tinggi Muhammadiyah, wajib diselenggarakan di Perguruan Tinggi Muhammadiyah sebagai ciri khas Perguruan Tinggi Muhammadiyah. Tidak terkecuali di Universitas Muhammadiyah Pekajangan Pekalongan. Universitas Muhammadiyah Pekajangan Pekalongan menyelenggarakan Pendidikan Al Islam dan Kemuhammadiyahan dengan merujuk pada pedoman pendidikan Al Islam dan Kemuhammadiyahan Perguruan Tinggi
Muhammadiyah dengan. Dalam upaya menjalankan pendidikan AIK secara maksimal sesuai dengan visi misi UMPP, Diterbitkanlah buku pedoman Pendidikan Al Islam dan Kemuhammadiyahan UMPP. Buku ini adalah hasil pengembangan dari pedoman pendidikan AIK yang diterbitkan oleh Majlis Diktilitbang PP Muhammadiyah.

Dalam buku pedoman Pendidikan $\mathrm{Al}$ Islam dan Kemuhammadiyahan UMPP bisa diketahui bahwa terdapat 5 (lima) mata kuliah AIK di UMPP yaitu : AIK 1 (Agama) yang membahas mengenai Ketuhanan dan Kemanusiaan; AIK 2 (Ibadah) yang membahas tentang ibadah meliputi Definisi dan Ruang Lingkup Islam, Thoharoh, Sholat, Dzikir Doa, Zakat, Puasa, Haji dan sebagainya; AIK 3 (Akhlak dan Muamalah) yang membahas mengenai Definisi dan Ruang Lingkup akhlak, akhlak terhadap Allah dan Rosululloh, Akhlak terhadap diri sendiri, keluarga dan lingkungan, jual beli dan sebagainya; AIK 4 (Kemuhammadiyahan) membahas mengenai sejarah Muhammadiyah, ideologi Muhammadiyah dan Gerakan Muhammadiyah; serta AIK 5 (Islam dan Ilmu Pengetahuan) yang membahas mengenai integrasi antara Agama dan Ilmu Pengetahuan. Masing-masing mata kuliah dari AIK 1, AIK 2, AIK 3, AIK 4 dan AIK 5 memiliki bobot 2 (dua) SKS.

Wakil rektor 1 UMPP, Bapak Moh. Arifin, S.Kep., M.Kep mengatakan bahwa AIK adalah mata kuliah yang wajib ada di PTM termasuk di UMPP, sehingga dalam pelaksanaannya harus mengacu pada pedoman 
yang diterbitkan oleh Majlis Diktilitbang PP Muhammadiyah. Sedangkan Wakil Dekan Bidang Akademik Fakultas Ilmu Kesehatan Bapak Dafid Arifiyanto, M.Kep. Sp.KMB menjelaskan bahwa semua Prodi di Fikes melaksanakan pendidikan AIK sesuai dengan pedoman pendidikan AIK di UMPP dan sebelum diterbitkan Buku pedoman pendidikan AIK UMPP juga sudah mengacu pada buku pedoman pendidikan AIK yang diterbitkan oleh STIKES Muhammadiyah Pekajangan Pekalongan

Mata Kuliah AIK di UMPP diampu oleh dosen-dosen dengan kualifikasi S-2 di bidang Agama Islam yang terdiri dari 3 (tiga) dosen tetap, dan 4 (empat) dosen tidak tetap, diantaranya adalah Gigih Setianto, M.Pd.I., Risdiani, M.S.I, Sumarno, M.Pd.I., Asfal Fuad, M.Pd., Moh. Muttaqin, M.S.I dan Moh. Zaini, M.Si.

Dari beberapa data diatas dapat diketahui bahwa UMPP telah melaksanakan mata kuliah Al Islam dan Kemuhammadiyahan sesuai dengan pedoman pendidikan yang diterbitkan oleh Majlis Pendidikan Tinggi Penelitian dan Pengembangan Pimpinan Pusat Muhammadiyah.

\section{Efektifitas matakuliah Al Islam dan}

\section{Kemuhammadiyahan (AIK) di Universitas}

Muhammadiyah Pekajangan Pekalongan

dalam pembentukan akhlakul karimah mahasiswa

Sesuai dengan buku pedoman Pendidikan AIK UMPP bahwa tujuan Mata Kuliah AIK di UMPP adalah untuk membentuk insan berkarakter dan insan terpelajar yang diharapkan memiliki integritas dan kesadaran etis dalam beramal shaleh baik yang bersifat ritual maupun sosial seharusnya tidak didasarkan pada faktor dari luar dirinya (ganjaran dan ancaman), melainkan sebagai bentuk panggilan etis, beramal shaleh sebagai manifestasi rasa terimakasih kepada Allah dan sesama. Pendidikan AIK juga untuk membentuk manusia berkemajuan, berjiwa pengasih, dan penuh kasih kepada sesama (philantropis).

Dari tujuan diatas maka dapat diketahui bahwa muara dari pendidikan AIK adalah akhlakul karimah, hal ini dikuatkan pula oleh Wakil Rektor III UMPP, Bapak Aslam Fatkhudin, M. Kom. Yang mengatakan bahwa pendidikan AIK di UMPP harus bisa menjadikan mahasiswa memiliki akhlakul karimah. Dosen AIK juga mengatakan hal serupa seperti yang disampaikan Ibu Risdiani MSI bahwa dalam pendidikan AIK tidak hanya sekedar menyampaikan teori, tapi bagaimana menjadikan mahasiswa memahami teori tersebut dan mau berubah menjadi lebih baik akhlaknya. Dosen AIK yang lain, Ibu Dra. Cholisa Rosanti, M.Si, mengatakan bahwa di mata kuliah AIK lengkap diajarkan bagaimana beraqidah yang baik, beribadah yang benar dan berakhlak yang mulia. Sementara Bapak Asfal Fuad, M.Pd. Dosen AIK juga mengungkapkan bahwa pendidikan AIK di UMPP yang terdiri dari Aqidah, Ibadah, Akhlak Muamalah, Kemuhammadiyahan serta Islam dan Ilmu Pengetahuan akan menguatkan habluminalloh, habluminannas dan hablumminal alam mahasiswa, yang mana ketiga hal itu adalah 
cerminan manusia yang bertakwa sebagai tujuan akhir pendidikan. Bapak Moh. Muttaqin, M.S.I sebagai dosen AIK juga mengatakan bahwa untuk membentuk mahasiswa yang berakhlakul karimah dirinya selalu mengajak diskusi mahasiswa terkait dengan menjaga hubungan baik dengan Allah, dengan sesama manusia dan dengan sesama makhluk Allah (alam). Dosen AIK yang lain, Bapak Sumarno, M.Pd.I juga mengatakan mata kuliah Agama (Aqidah) dan Ibadah mengajarkan bagaimana mahasiswa berakhlak kepada Allah dengan sebaik-baiknya, Mata kuliah Akhlak dan Muamalah, kemuhammadiyah dan Islam Ilmu Pengetahuan mengajarkan akhlak kepada sesama manusia dan Akhlak kepada Lingkungan. Karena itulah AIK ini menjadi satu kesatuan yang tidak bisa dipisahkan.

Dari data diatas maka dapat diketahui bahwa baik rektorat, dekanat dan dosen AIK di Universitas Muhammadiyah Pekajangan Pekalongan telah memiliki pemahaman yang sama dalam pembentukan akhlakul karimah mahasiswa melalui mata kuliah AIK dan berusaha kuat untuk menjadikan mata kuliah AIK sebagai pembentuk Akhlakul Karimah Mahasiswa.

\section{Analisis Efektifitas Mata Kuliah Al Islam dan Kemuhammadiyahan dalam pembentukan akhlakul karimah terhadap} Allah

Yang dimaksud akhlak terhadap Allah atau hubungan manusia dengan Allah adalah sikap dan perbuatan yang seharusnya dilakukan oleh manusia terhadap Allah. Akhlak terhadap
Allah meliputi beribadah kepada Allah, mentauhidkan Allah, berdoa, berdzikir dan bersyukur serta tunduk dan taat hanya kepada Allah.

Dalam buku pedoman pendidikan AIK UMPP dengan jelas bisa di ketahui bahwa di mata kuliah AIK 1 (Aqidah) diajarkan bagaimana beriman, bertauhid, beraqidah yang benar, sekaligus cara cara untuk menanggulangi perbuatan syirik. Kemudian di AIK 2 (Ibadah) juga diajarkan bagaimana beribadah yang baik dan benar termasuk di dalamnya Thoharoh, Solat, Dzikir dan Doa, Sujud Syukur dan sebagainya. Menurut peneliti mata kuliah AIK 1 (Aqidah) dan AIK 2 (Ibadah) ini secara langsung ditujukan untuk membentuk akhlakul karimah mahasiswa terhadap Allah SWT.

$\mathrm{Hal}$ ini juga diperkuat dengan pernyataan M. Nur Sukma Aji, mahasiswa Fisioterapi Fikes UMPP yang mengatakan bahwa dalam mata kuliah AIK 1 (Aqidah) diajarkan cara bertauhid yang benar, juga di AIK 2 (Ibadah) diajarkan cara beribadah yang benar seperti sholat, berdoa, berdzikir, yang semua itu kemudian menjadi amalan-amalan dalam kehidupan sehari-hari. Setelah diajarkan itu, ia menjadi tahu bagaimana bertauhid yang baik seperti berdoa hanya kepada Allah, tidak percaya kepada tahayul, tidak memelihara jimat, tidak mendatangi dukun. Selain itu juga setalah diajarkan AIK juga menjadi tahu kaifiyat thoharoh, sholat, zakat, puasa, haji dan ibadah yang lain. Demikian juga mahasiswa yang lain Nikmah Honest, mahasiswa keperawatan Fikes mengatakan bahwa adanya mata Kuliah Aqidah 
menjadikan ia tahu tentang hakikat laa ilaaha illa Allah, dan dari situlah ia semakin yakin bahwa ia adalah hamba yang diciptakan oleh Allah dan harus beribadah dengan Allah. Selain itu ia menjadi semakin bersyukur atas nikmat kehidupan, kesehatan, rezeki yang selama ini diberikan oleh Allah sebagai Roobul Alamin. Hesti Yulianti mahasiswa FEB UMPP mengatakan bahwa setelah mengikuti AIK, semakin beriman kepada Allah, semakin yakin bahwa nikmat datangnya dari Allah dan Ujian juga datangnya dari Allah. Sementara Yuli Prabowo mahasiswa Fastikom UMPP mengatakan bahwa setelah mendapat mata kuliah AIK ia lebih berhati hati terhadap perilaku syirik yang sekarang banyak dilakukan masyarakat. Dia berusaha menjauhi karena perilaku syirik adalah dosa besar. M. Faishol mahasiswa Diploma Tiga Keperawatan yang juga presiden BEM juga mengatakan bahwa setelah mengikuti Mata Kuliah AIK ia menjadikan dirinya lebih taat beribadah kepada Allah seperti Sholat, juga lebih memiliki sifat sabar dalam menjalani kehidupan.

Sementara itu Zaki, Mahasiswa Diploma Tiga Keperawatan Fikes UMPP Mengatakan selama mengikuti mata kuliah AIK diajarkan tentang Aqidah, Tauhid dan Syirik sehingga setelah mengikuti mata kuliah AIK ini ia berusaha sekuat tenaga untuk tidak melakukan perbuatan syirik, utamanya syirik modern yang sekarang banyak menjangkiti anak anak muda, selain itu juga ia mengatakan setelah mengetahui hakikat tauhid, ia mengatakan lebih bisa bersyukur dan bersabar dalam menjalani kehidupan.

Dari wawancara diatas maka dapat diketahui bahwa Mata Kuliah AIK efektif membentuk akhlakul karimah mahasiswa terhadap Allah meliputi bertauhid yang benar, berdoa hanya kepada Allah, tidak percaya tahayul, tidak memelihara jimat, tidak mendatangi dukun, bersyukur atas nikmat Allah, bersabar atas ujian dari Allah, beribadah yang baik seperti thoharoh, Sholat, Zakat, Puasa dan sebagainya.

\section{Analisis Efektifitas Mata Kuliah Al Islam dan Kemuhammadiyahan dalam pembentukan akhlakul karimah terhadap} Sesama

Akhlak terhadap manusia digolongkan menjadi tiga yaitu; Akhlak terhadap diri sendiri, akhlak terhadap keluarga, dan akhlak terhadap orang lain atau masyarakat.

Akhlak terhadap diri sendiri adalah pemenuhan kewajiban manusia terhadap dirinya sendiri, baik yang menyangkut jasmani maupun rokhani. Diantara yang termasuk akhlak terhadap diri sendiri adalah jujur dan dapat dipercaya, bersikap sopan santun, sabar, kerjakeras dan disiplin, berjiwa ikhlas, hidup sederhana.

Dalam buku pedoman pendidikan AIK UMPP dengan jelas bisa di ketahui bahwa di mata kuliah AIK 3 (Akhlak dan Mumalah) diajarkan bagaimana berakhlak terhadap diri sendiri, berakhlak terhadap sesama manusia dan berakhlak terhadap lingkungan. Kemudian di AIK 4 (Kemuhammadiyahan) juga diajarkan bagaimana kepribadian Muhammadiyah ini bisa 
melekat pada diri setiap mahasiswa meliputi Aqidah, Akhlak, Ibadah dan Mumalah yang sesuai dengan Al Quran dan Sunnah. Menurut peneliti mata kuliah AIK 3 (Aqidah) dan AIK 4 (Kemuhammadiyahan) ini secara langsung ditujukan untuk membentuk akhlakul karimah mahasiswa terhadap sesama dan Akhlakul karimah terhadap lingkungan.

M. Nur Sukma Aji mengatakan bahwa setelah mengikuti kuliah AIK, ia menjadi pribadi yang lebih jujur, dan pekerjakeras. Terlebih dalam bergaul dengan sesama, ia menyadari bahwa bohong tidak akan membawa kepada ketenangan. Dalam usaha menyelesaikan skripsi juga ia menyadari harus bekerja keras karena Allah tidak akan mengubah keadaan pada diri manusia melainkan dirinya sendiri berusaha untuk mengubahnya dan salah satu upayanya ia harus bekerja keras menulis, mengumpulkan data dan menganalisis. Selain itu ia menjadi lebih sabar dalam menghadapi masalah yang terjadi dalam kehidupannya. Selanjutnya Nikma Honest mengatakan bahwa setelah mengikuti AIK ini dia menjadi orang yang lebih amanah. Ia mengatakan jabatan sebagai ketua Korkom IMM UMPP lebih dijalankan secara amanah, selain itu juga lebih sabar dalam menghadapi teman teman diorganisasi, disiplin dan sederhana dalam menjalani kehidupan. Hesti menambahkan bahwa setelah kuliah AIK, ia menjadi lebih jujur, amanah dan bersikap sopan santun. Yuli Prabowo juga mengakui bahwa setelah mendapat mata kuliah AIK ia berusaha untuk jujur dalam bersikap, dan juga belajar untuk sopan santun kepada siapa saja. Faishol menambahkan setelah mendapatkan mata kuliah AIK ini menjadikan lebih bertanggungjawab dan percaya diri. Sementara Zaki mengatakan bahwa di AIK diajarkan akhlak terhadap diri sendiri,sehingga dirinya bisa mau bermuhasabah atas kesalahan.

Dari data diatas dapat diketahui bahwa mata kuliah AIK terbukti efektif dalam membentuk akhlakul karimah terhadap diri sendiri meliputi jujur, pekerjakeras, amanah, disiplin, sederhana, sopan santun, percaya diri dan mau introspeksi diri.

Sedangkan Akhlak terhadap keluarga didalamnya adalah hubungan antara orang tua dengan anak, suami dan istri hendaklah terjaga dengan serasi. Kewajiban masing masing anggota keluarga dituntut untuk ditunaikan sebaikbaiknya. Demikian juga hak-hak masing masing anggota keluarga harus diberikan seadil-adilnya. Diantara yang termasuk akhlak dalam keluarga adalah Berbuat baik kepada orang tua dan kerabat, menghormati hak hidup anak, membiasakan bermusyawarah, bergaul dengan yang baik,menyantuni saudara yang kurang mampu.

M. Nur Sukma Aji mengatakan bahwa setelah mengikuti mata kuliah AIK dia menjadi tahu tentang bagaimana kewajiban anak terhadap orang tua, sehingga dia berusaha untuk membahagiakan orang tua, hal yang paling mudah menurut yang dia lakukan adalah dengan tidak membantah perintah orang tua dan berusaha berkomunikasi yang baik dengan orang tua. Sedangkan nikmah honest menyatakan bahwa hubungan baik yang ia lakukan selama ini dengan keluarga adalah dengan menghormati 
kerabat serta memutuskan sesuatu dengan bermusyawarah bersama keluarga. Hesti juga menyatakan bahwa sekarang dirinya berusaha untuk birrul walidain. Yuli Prabowo menjelaskan bahwa AIK mengejarkan dia untuk menyayangi keluarga. Sementara Faishol mengatakan setelah mendapatkan mata kuliah AIK berusaha untuk tidak menyusahkan orang tua apalagi sampai menjadikan orang tua kecewa. Sementara Zaki mengatakan bahwa di AIK diajarkan akhlak terhadap keluarga yang menjadikan dirinya berusaha meringankan beban orang tua.

Dari data diatas dapat diketahui bahwa mata kuliah AIK terbukti efektif dalam membentuk akhlakul karimah terhadap keluarga meliputi berbakti kepada orang tua, menjalin silaturohim dengan keluarga, bermusyawarah dengan keluarga, menyanyangi anggota keluarga, meringankan beban orang tua.

Kemudian Akhlak terhadap orang lain (masyarakat) maksudnya dalam bermasyarakat kita hidup berdampingan dengan orang lain. Dalam hidup kita pasti akan selalu membutuhkan bantuan orang lain. Oleh karena itu berakhlakul karimah terhadap orang lain menjadi suatu keharusan. Wujud akhlak tehadap orang lian adalah dengan saling tolong menolong dalam berbuat kebaikan. Membantu kaum mustadzafin, tidak sombong dan tidak angkuh.

M. Nur Sukma Aji mengatakan bahwa AIK mengajarkan dia untuk peduli terhadap orang lain terutama fakir miskin dan anak yatim, makanya dia berusaha menyisihkan uang sakunya untuk diberikan kepada kaum mustadzafin tersebut, sementara nikma honest menyatakan bahwa AIK mengajarkan dia untuk bekerjasama dalam kebaikan, tolong menolong dan gotong royong dalam menyelesaikan tugas tugas keumatan termasuk dalam berorganisasi . Hesti menambahkan bahwa sekarang ia menggerakan teman-temannya untuk memberi bantuan kepada yang membutuhkan, hal ini ia lakukan setelah mendapat materi tentang teologi al maun dalam AIK. Yuli juga mengatakan yang sama yaitu sekarang ia berusaha untuk bisa membantu orang yang membutuhkan lebih-lebih dimasa pandemi sekarang. Sedangkan Faishol mengatakan setelah mendapatkan mata kuliah AIK menjadikan dirinya bisa menerima perbedaan. Sementara Zaki mengatakan bahwa di AIK akhlak terhadap orang lain sehingga menjadikan dirinya bisa lebih menghargai dan toleransi.

Dari data diatas dapat diketahui bahwa mata kuliah AIK terbukti efektif dalam membentuk akhlakul karimah terhadap orang lain (masyarakat) meliputi Peduli terhadap kaum mustadzafin, tolong menolong, gotong royong, toleransi.

\section{Analisis Efektifitas Mata Kuliah Al Islam dan Kemuhammadiyahan dalam pembentukan akhlakul karimah terhadap alam Lingkungan}

Akhlak terhadap lingkungan adalah memanfaatkan potensi alam untuk kepentingan hidup manusia. Namun harus tidak boleh boros dan merusak yang berakibat kerusakan alam itu sendiri. Menjaga kebersihan juga merupakan akhlak yang baik terhadap alam. Akhlak yang baik terhadap alam akan dapat mengurangi 
bencana alam yang setiap saat dapat menimpa kehidupan manusia.

Dalam buku pedoman pendidikan AIK UMPP Didalam mata kuliah AIK 3 (Akhlak dan Muamamalah) salah satu bab pembahasannya adalah akhlak terhadap alam/ lingkungan yang membahasa tentang eksistensi alam, dan bagaimana seharusnya manusia berakhlak terhadap alam/lingkungan.

M. Nur Sukma Aji mengatakan bahwa AIK mengajarkan dia untuk peduli terhadap alam, dengan berusaha untuk tidak membuang sampah sembarangan dan tidak boros dalam menggunakan air, sementara Nikma Honest mengatakan bahwa AIK menyadarkan dia untuk peduli terhadap lingkungan dengan berusaha mengurangi sampah plastik. Hesti menyatakan juga sekarang ia sadar bahwa membuang sampah sembarangan akan merusak lingkungan dan itu bertentangan dengan agama, ia berusaha mulai dari hal yang kecil yaitu membuang sampah ke tempat sampah. Yuli menambahkan ia selalu membuka diskusi dengan teman temannya tentang aktifitas pertambangan yang merusak lingkungan sebagai bentuk kepeduliannya terhadap lingkungan dan sebagai upaya menghentikan penambangan tersebut. Sedangkan Faishol mengatakan bahwa setelah mendapatkan mata kuliah AIK dirinya lebih bisa menjaga kelestarian lingkungan dengan menanam tanaman di lingkungan rumah. Sementara Zaki mengatakan kaitan dengan akhlak terhadap lingkungan, setelah mendapatkan mata kuliah AIK dia menjadi tidak mau membuang sampah sembarangan, serta lebih menyayangi binatang.

Dari data diatas dapat diketahui bahwa mata kuliah AIK terbukti efektif dalam membentuk akhlakul karimah terhadap alam meliputi tidak membuang sampah sembarangan, hemat dalam penggunaan air bersih, mengurangi sampah plastik, menolak penambangan yang merusak lingkungan, menjaga kelestarian lingkungan dengan menanam tanaman dan peduli terhadap binatang.

\section{KESIMPULAN}

Berdasarkan hasil penelitian Efektifitas Mata Kuliah Al Islam dan Kemuhammadiyahan dalam Pembentukan Akhlakul Karimah Mahasiswa Universitas Muhammadiyah Pekajangan Pekalongan dapat disimpulkan bahwa: Mata Kuliah Al Islam dan Kemuhammadiyahan efektif dalam pembentukan akhlakul karimah mahasiswa baik akhlakul karimah terhadap Allah, Akhlakul karimah terhadap manusia dan akhlakul karimah terhadap alam lingkungan.

Secara lebih terinci pembentukan akhlakul karimah terhadap Allah meliputi bertauhid yang benar, berdoa hanya kepada Allah, tidak percaya tahayul, tidak memelihara jimat, tidak mendatangi dukun, bersyukur atas nikmat Allah, bersabar atas ujian dari Allah, beribadah yang benar seperti thoharoh, Sholat, Zakat, Puasa dan sebagainya. Pembentukan akhlakul karimah terhadap diri sendiri meliputi jujur, pekerjakeras, amanah, disiplin, sederhana, sopan santun, percaya diri dan mau introspeksi diri. Pembentukan akhlakul karimah terhadap 
keluarga meliputi berbakti kepada orang tua, menjalin silaturohim dengan keluarga, bermusyawarah dengan keluarga, menyanyangi anggota keluarga, meringankan beban orang tua. Pembentukan akhlakul karimah terhadap orang lain meliputi Peduli terhadap kaum mustadzafin, tolong menolong, gotong royong, toleransi. Sedangkan pembentukan akhlakul karimah terhadap alam/lingkungan meliputi tidak membuang sampah sembarangan, hemat dalam penggunaan air bersih, mengurangi sampah plastik, menolak penambangan yang merusak lingkungan, menjaga kelestarian lingkungan dengan menanam tanaman dan peduli terhadap binatang.

\section{DAFTAR PUSTAKA}

Abdurrahman, D. (2003). Pengantar Metode Penelitian. Kurnia Kalam.

Al Abrashi, A. (1967). Education in Islam. The Supreme Council for Islamic Affair.

al Ghozali, I. (1967). Ihya Ulumuddin. Isa Bab al Halabi.

Amin, A. (tt). Kitab al Akblak. Dar al Kutub al Misriyah.

Arikunto, S. (2007). Manajemen Penulisan. Rineka Cipta.

Assyaibani, O. M. al T. (1972). Falsafah Pendidikan Islam. Bulan Bintang.

Maskawaih, I. (1934). Tahdzib al Akblak wa Tathbiru al A'raq. Al Maktabah al Misyrish.

Moleong, L. J. (2007). Metodologi Penelitian Kualitatif. Remaja Rosda Karya.

Rajab, M. A. (1961). Taammulat fi Falfati alAkblak. Maktabah Injalu.

S. Margono. (2004). Metode Penelitian Pendidikan.
Rineka Cipta.

Shindunata. (2000). Menggagas Pendidikan Baru Pendidikan Demokratisasi, Otonomi, Civil Society Globalisasi. Tiara Wacana.

Shobron, S. (2015). Studi Islam 1. LPIK UMS.

Lestari, S \& Ngatini. (2010). Pendidikan Islam Kontekstual. Pustaka Pelajar.

Sugiyono. (2010). Metode Penelitian Pendidikan: Pendekatan Kuantitatif dan Kualitatif. Alfabeta.

Suhaimi. (2014). Islamisasi Ilmu Pengetahuan Telaah Kritis Pemikiran Ismail Raji alFaruqi. Jurnal Al-Ulum, Jurnal Pemikiran dan Penelitian ke-Islaman, 1, 189.

Suraji, I. (2006). Etika dalam Perspektif Al-Quran dan Hadits. PT. Pustaka Al Husna Baru.

Syukur, A. (2010). Studi Akblak. Wali Songo Press.

Tim Pedoman Pendidikan AIK Majlis Dikti PP Muhammadiyah. (2013). Pedoman Pendiikan Al Islam dan Kemuhammadiyahan Perguruan Tinggi Muhammadiyah. Majlis Dikti PP Muhammadiyah.

Tim Pimpinan Pusat Muhammadiyah. (2010). Berita Resmi Mubammadiyah: Tanfidz. Keputusan Muktamar Satu Abad Muhammadiyah (Muktamar Muhammadiyah Ke 46). Pimpinan Pusat Muhammadiyah.

Surahmad, Winarno \& dkk. (2003). Mengurai Benang Kusut Pendidikan di Indonesia. Transformasi.

Yakub, H. (1983). Etika Islam. CV. Diponegoro. 